Ann. Biol. anim. Bioch. Biophys., 1979, 19 (3 B), 929-935.

\title{
Urea cycling and ammonia absorption in vivo in the digestive tract of the rat
}

\author{
par C. DEMIGNÉ and C. RÉMÉSY \\ Laboratoire de Moladies Méfaboliques, I.N.R.A., \\ Theix, Saint-Genès-Champanelle, 63110 Beaumont, France.
}

Summary. The transfer of blood urea into the digestive tract and ammonia absorption at that site have been studied in vivo in anesthetized rats. The vein-artery differences in urea and ammonia absorption were greater in the caecum than in the ileum. The urea load indicated that blood urea was an important factor in ammonia production. Carbohydrate substrates in the caecum (cell-wall carbohydrates or lactose) increased caecal size and volatile fatty acid production. In these conditions, blood urea uptake increased ; moreover, acidification of the caecal content did not decrease ammonia absorption, despite a drop in the $\mathrm{NH}_{3}$ form, which is considered as the most diffusible. Urea transfer and ammonia absorption were highest with high-protein diets when accompanied by considerable caecal fermentation. As compared to the predominant role of blood urea level and of caecal development (blood flow, surface of exchange, ureolytic activity), caecal $\mathrm{pH}$ seemed to be a less important factor. This observation could correspond to urea hydrolysis near the caecal wall in different conditions of $\mathrm{pH}$ and substrate than those found throughout the caecum.

\section{Introduction.}

Nitrogen reaching the caecum is mainly of endogenous origin, the protein and urea coming from the small intestine, or the urea coming directly from the blood. Urea nitrogen transfer and ammonia production have been studied in the caecum of various rodents, especially rabbits (Hoover and Heitmann, 1975 ; Knutson et al., 1977) as a part of the nitrogen used in bacterial synthesis is re-utilized after coprophagy. The ammonia produced is partly reabsorbed in the blood, and reaches the liver where it must be completely detoxified into urea. This problem has been particularly studied in human subjects showing inadequate ammonia uptake by the liver and where it was necessary to ensure minimal ammonia absorption in the colon (Bircher ef al., 1966 ; Vince ef al., 1973). However, nitrogen digestion in the caecum has seldom been defined by vein-artery differences. This study considers the influence of carbohydrates poorly digested in the small intestine on the intensity of blood urea utilization and ammonia absorption. 


\section{Material and methods.}

Animals and diets. - Male Sherman rats weighing 200 to $250 \mathrm{~g}$ and fed ad libitum were adapted to successive light/dark periods (dark from $9.00 \mathrm{~h}$ to $21.00 \mathrm{~h}$ ). They were given a standard chow (Sanders, Juvisy/Orge) or semi-purified diets. The standard chow contained percentages of the following : cereals 62 , soya-bean meal 28 (50 p. 100 protein), molasses 5 , salts and vitamins 5 . The semi-purified diets included a control diet : casein 15, wheat starch 74 ; a lactose diet : casein 15, wheat starch 54, lactose 20 ; a high-protein diet : casein 50, wheat starch 39 ; a high protein and lactose diet : casein 50 , wheat starch 19, lactose 20. All the semi-purified diets contained 5 p. 100 corn oil, 5 p. 100 salt mixture and 1 p. 100 vitamin mixture; the salt and vitamin mixtures were supplied by UAR (Villemoisson/Orge).

Experimental procedures. - Rats that had been fed on one of the diets for 10 to 14 days were anesthetized with Nembutal $(40 \mathrm{mg} / \mathrm{kg}$ ) at $16.00 \mathrm{~h}$. After abouf $30 \mathrm{~min}$, 0.6 to $0.8 \mathrm{ml}$ of blood was taken from an ileal vein then from the aorta, or from the caecal vein then from the aorta. Fresh weight samples of about $1 \mathrm{~g}$ of digestive contents were placed in Eppendorf microtubes and immediately frozen at $-20^{\circ} \mathrm{C}$. Urea load was administered to $250 \mathrm{~g}$ fed rats by subcutaneous injection of $100 \mathrm{mg}$ of urea $30 \mathrm{~min}$ before blood sampling.

Metabolite determination. - After the plasma was treated with 2 parts $0.6 \mathrm{M} \mathrm{HClO}_{4}$ and the digestive contents with 10 parts $0.4 \mathrm{M} \mathrm{HClO}_{4}$, the ammonia and urea were enzymatically determined (Gutmann and Bergmeyer, 1974 ; Kun and Kearney, 1974). Volatile fatty acids (VFA) from the digestive contents were measured after centrifugation (9000 g, $2 \mathrm{~min}$ ) using an acidified supernatant (Rémésy and Demigné, 1976). Using lithium buffers, amino acids were determined in the plasma and the caecal contents after deproteinization by 5 p. 100 sulphosalicylic acid $(1: 4, v / v)$, as described by Rémésy, Demigné and Aufrère (1978).

TABLE 1

Urea and ammonia concentrations in plasma and digestive contents ( $m M$ ) and vein-artery differences in the ileum and the caecum

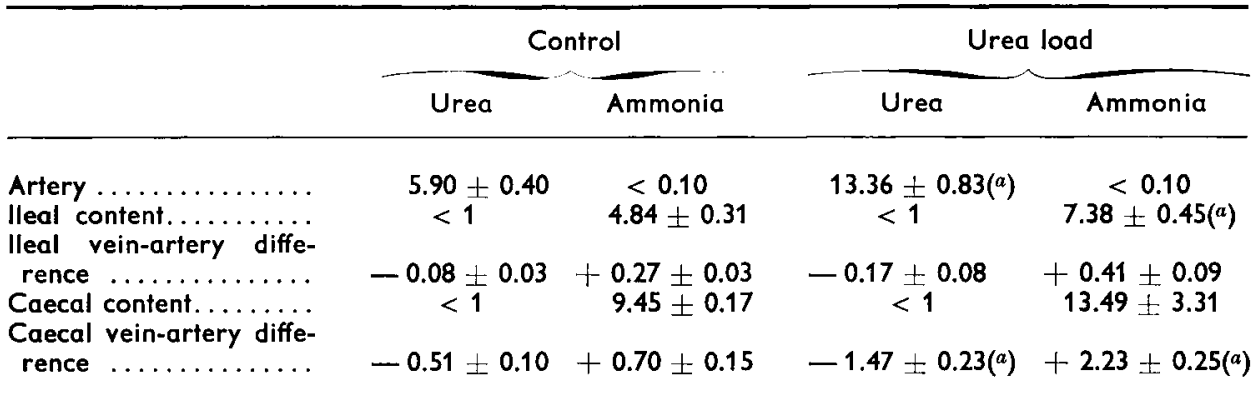

Each value is the mean \pm SEM for 10 rats.

$(a)$ : significant differences between control and urea load $(P<0.05)$. Positive vein-artery differences correspond to net absorption, and negative vein-artery differences to net transfer into the digestive contents. 
The data were expressed as means \pm SEM ; the statistical significance of the differences between means was assessed with the Student's $t$ test.

\section{Results.}

Caecal amino acid balance. - With the standard chow, there is only a favorable gradient for absorption of taurine, glutamate and aspartate; the following levels were found in the caecal contents and the arterial plasma, respectively: taurine 0.69 and $0.10 \mathrm{mM}$, glutamate 1.10 and $0.04 \mathrm{mM}$, aspartate 0.30 and $0.01 \mathrm{mM}$. A significant caecal vein-artery difference was found only for taurine $(0.1 \mathrm{mM})$. Caecal concentrations of the other amino acids were lower than or equal to the arterial levels and no significant vein-artery differences were noted.

Influence of blood urea an ammonia reabsorption in the digestive tract. - Nitrogen reaches the caecum through the ileum either as endogenous or non-digested proteins or as blood urea. Table 1 shows that the concentration gradient between the digestive contents and the blood always favored the transit of urea fowards the intestine, where urea is very low due to bacterial urease activities (Moreau, Ducluzeau and Raibaud, 1976). Vein-artery differences alone did not give quantifative data on the transfer of urea, but did provide an estimate of digestive tract permeability to urea. The caecal wall thus appeared more permeable to urea than the small intestine wall. Ammonia was produced in the ileum, but to a lesser extent than in the caecum, probably owing to reduced urea availability and to a less active bacterial metabolism. The vein-artery differences were greater in the caecum than in the ileum, and the caecum seemed to be the main site of ammonia production in the rat digestive tract. When arterial urea increased, vein-artery differences in urea and ammonia were greater. Thus, enhanced uremia is probably the main factor responsible for the well-known increase in ammonia absorption with high-protein diets.

TABLE 2

Caecal development and end-products of caecal flora

\begin{tabular}{|c|c|c|c|}
\hline & $\begin{array}{l}\text { Crude cereal and } \\
\text { seed-cake diet }\end{array}$ & $\begin{array}{l}\text { Semi-purified diet } \\
\text { (74 p. } 100 \text { wheat } \\
\text { starch) }\end{array}$ & $\begin{array}{l}\text { Semi-purified diet } \\
\text { (20 p. } 100 \text { lactose) }\end{array}$ \\
\hline 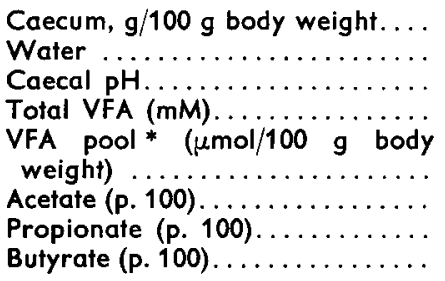 & $\begin{array}{c}2.5 \pm 0.2 \\
77.0 \pm 0.4 \\
6.20 \pm 0.10 \\
182.5 \pm 6.1 \\
351 \\
58.1 \pm 0.9 \\
24.3 \pm 1.1 \\
17.6 \pm 0.8\end{array}$ & $\begin{aligned} 1.1 & \pm 0.1\left({ }^{a}\right) \\
76.4 & \pm 0.5 \\
7.32 & \pm 0.07(a) \\
116.8 & \pm 3.5(a) \\
& 98 \\
68.6 & \pm 0.8\left(^{a}\right) \\
26.6 & \pm 0.6 \\
4.8 & \pm 0.8(a)\end{aligned}$ & $\begin{array}{c}2.5 \pm 0.1\left(^{b}\right) \\
83.0 \pm 0.4\left(^{b}\right) \\
5.66 \pm 0.12\left({ }^{b}\right) \\
161.9 \pm 7.4\left(^{b}\right) \\
336 \\
50.2 \pm 2.0\left(^{b}\right) \\
13.2 \pm 1.4\left(^{b}\right) \\
36.6 \pm 2.4\left(^{b}\right)\end{array}$ \\
\hline
\end{tabular}

Each value is the mean \pm SEM for 10 rats except with the 20 p. 100 lactose dief using 17 rats Significant differences $(P<0.05)$ are indicated by :

(a) : semi-purified diet (wheat starch) vs crude cereal and seed-cake diet ;

(b) : semi-purified diet (20 p. 100 lactose), vs semi-purified diet (74 p. 100 wheat starch).

* : The pool of VFA for $100 \mathrm{~g}$ body weight was calculated in the following way : VFA concentration $\times$ caecal weight $(\mathrm{g} / 100 \mathrm{~g}$ body weight $) \times$ water percentage. 
Influence of dietary fermentable carbohydrates on caecal ammonia absorption. - With the standard chow, including crude cereal and seed-cake, there was a very high concentration of VFA in the caecum, similar to or higher than that in the rabbit caecum (Henning and Hird, 1972) or in the rumen (Bergman et al., 1965 ; Davis, 1967 (table 2). With the semi-purified diets, using readily digestible starch, the caecum was small and there were few VFA, with a large proportion of acetate and very little butyrate. Lactose enhanced caecal weight and VFA concentrations; some fermentations were particularly rich in butyrate, but a noticeable proportion of the rats had fermentations rich in propionate (25 p. 100) or with similar amounts of propionate and butyrate (14 p. 100) (results not shown).

Blood urea uplake increased when the caecum was larger (microbial activity, larger surface of exchange). Thus, with the 15 p. 100 casein diet, lactose lowered caecal $\mathrm{pH}$ and ammonia concentration, while the $\mathrm{pH}$ decreased without change of total ammonia with the 50 p. 100 casein diet (table 3). The concentration of $\mathrm{NH}_{3}$, considered as the most readily diffusible form, was very markedly reduced. Despite this, the veinartery difference in ammonia was greater with the lactose-rich diets. In these conditions, there was no correlation between the concentrations of ammonia in the caecum and its absorption. However, when the caecal vein-artery difference in ammonia $N$ and urea $\mathrm{N}$ was compared, the balance corresponded to a quantitative recovery of blood urea as ammonia with the fermentation-poor diet, while lactose decreased this recovery. There was thus an inverse correlation between carbohydrate availability and the proportion of urea nitrogen recovered in the blood as ammonia.

TABLE 3

Ammonia concentrations in caecal contents and vein-artery differences in ammonia and urea $(\mathrm{mM})$ in rats fed semi-purified diets including various levels of lactose and protein

\begin{tabular}{|c|c|c|c|c|}
\hline & Control diet & $\begin{array}{l}20 \text { p. } 100 \\
\text { Lactose diet }\end{array}$ & High-protein diet & $\begin{array}{c}\text { High-protein } \\
20 \text { p. } 100 \text { lactose di }\end{array}$ \\
\hline $\begin{array}{l}\text { Caecal weight, g.............. } \\
\text { Caecal } \mathrm{pH} . \ldots \ldots \ldots \ldots \ldots \\
\text { Caecal } \mathrm{NH}_{3}+\mathrm{NH}_{4}^{+} \ldots \ldots \ldots \ldots \\
\text { Caecal } \mathrm{NH}_{3}^{*} \ldots \ldots \ldots \ldots \ldots \ldots \\
\text { Urea, artery } \ldots \ldots \ldots \ldots \ldots \\
\text { Urea, caecal vein-artery diffe- } \\
\text { rence. } \ldots \ldots \ldots \ldots \ldots \ldots \\
\text { Ammonia, caecal vein-artery } \\
\text { difference } \ldots \ldots \ldots \ldots \ldots \ldots\end{array}$ & $\begin{array}{r}2.33 \pm 0.12 \\
7.42 \pm 0.06 \\
15.95 \pm 1.10 \\
0.401 \\
4.43 \pm 0.17 \\
-0.20 \pm 0.12 \\
-0.38 \pm 0.07\end{array}$ & $\begin{aligned} 5.76 \pm 0.23\left({ }^{a}\right) \\
5.66 \pm 0.10\left(^{a}\right) \\
2.57 \pm 0.36\left(^{a}\right) \\
0.001 \\
4.24 \pm 0.21 \\
-0.53 \pm 0.08\left(^{a}\right) \\
+0.53 \pm 0.08\end{aligned}$ & $\begin{aligned} 1.95 & \pm 0.18 \\
7.99 & \pm 0.13\left(^{a}\right) \\
19.47 & \pm 1.61 \\
1.816 & \\
11.61 \pm 0.85\left({ }^{a}\right) & \\
-0.33 & \pm 0.10 \\
+-0.67 & \pm 0.10\left({ }^{a}\right)\end{aligned}$ & $\begin{aligned} & 5.33 \pm 0.39(a, b) \\
& 5.93 \pm 0.05(a, b) \\
& 21.86 \pm 1.00(a, c) \\
& 0.018 \\
& 9.39 \pm 0.36(a, c) \\
&-0.95 \pm 0.17\left(^{a, b, c}\right. \\
&+1.52 \pm 0.25(a, b, c\end{aligned}$ \\
\hline
\end{tabular}

Each value is the mean \pm SEM for 10 rats. Significant differences $(P<0.05)$ are indicated by :

$\left({ }^{a}\right)$ : all diets vs control ;

${ }^{(b)}$ : high-protein and lactose diet vs high-protein diet ;

$(c)$ : lactose diet vs high-protein and lactose diet.

* The caecal $\mathrm{NH}_{3}$ was calculated with the formula $\left[\mathrm{NH}_{3}\right]=\left[\mathrm{NH}_{4}^{+}\right] \times 10^{(\mathrm{pH}-\mathrm{pK})}$, assuming that a) in the range of $\mathrm{pH}$ encountered in the caecal contents, the non-ionized $\mathrm{NH}_{3}$ form is always very small a compared to the ionized form ; b ) the $\mathrm{pK}$ of $\mathrm{NH}^{+} \rightleftharpoons \mathrm{NH}_{3}$ reaction is 9.02 . 
With a high-protein diet resulting in high blood urea, larger quantities of urea reached the caecum and ammonia absorption increased. Also, the lactose in this diet did not significantly reduce the ammonia concentration in the caecum, and there was even maximal ammonia absorption, as the caecal size and the blood urea level were both considerable.

\section{Discussion.}

The highest number of bacteria in rats is found in the caecum and bacterial equilibrium may be modified by dietary carbohydrates (Lee and Gemmel, 1972 ; Raibaud et al., 1972). In spite of the different substrates available for caecal fermentations, the end-products of the flora are VFA in the large intestine of all mammalian species (Argenzio, Miller and von Engelhardt, 1975). Other organic acids seem to be only intermediary products and they seldom accumulate in the caecum (Marty, Raynaud and Carles, 1973), except for lactic acid when the $\mathrm{pH}$ is about 5 (Rémésy, Demigné and Aufrère, 1977). It has been observed in rumen fermentation that the proportion of acelate is highest with about $\mathrm{pH} 7$, when fermentations are rater slow. With a more acid $\mathrm{pH}$, the proportion of acetate is generally lower and there is a higher percentage of propionate or butyrate, depending on the flora and the carbohydrates. The lactase activity of the small intestine apparently does not adapt efficiently to a high-lactose diet and Kim, Benevenga and Grummer (1978) found that 30 to 40 p. 100 of the consumed lactose became available for fermentations in the large intestine. The rate of carbohydrate fermentation is probably the main factor causing the $\mathrm{pH}$ to drop and the percentage of propionate or butyrate to increase. The heterogeneity of propionate and butyrate concentrations with lactose can probably be explained by a difference in bacterial flora.

The relationship between carbohydrate and nitrogen flora digestion is obvious since numerous bacteria use the energy from carbohydrates to synthesize proteins. The recovery of nitrogen via the absorption of amino acids synthesized by bacteria is still questionable (Slade et al., 1969). In fact, vein-artery differences in free amino acids which we observed suggested that the $\alpha-\mathrm{NH}_{2}$ nitrogen balance is very slight in the caecum, except for taurine (possibly originating from bile salts). In any case, the amino acid concentration gradient between blood and caecal contents did not indicate noticeable exchanges between these two compartments, except for glutamate and aspartate, which were more concentrated in the caecal contents.

Urea hydrolysis seemed to be permanent and increased according to the amounts of carbohydrate digested. However, much of the ureolytic activity is attributable to some strains of Lactobacilli, according to Ducluzeau et al. (1966). Thus, lactose diets could favor a particularly ureolytic microflora. We cannot confirm the findings of Vince et al. (1973), who observed that flora urease activity decreased with the $\mathrm{pH}$ of the digestive contents : acidification ought to decrease ammonia absorption, but caecal enlargement, due to readily fermentable carbohydrates, increased blood urea uptake and ammonia absorption. In humans, acidification of the colon content by lactulose intake (Conn et al., 1977 ; Vince, Killingley and Wrong, 1978) is probably not accompanied by an increase in colon size and urease activity. On the other hand, Wolpert, Phillips and Summerskill 
(1971) claimed that urea permeability of the human colon is slight, being much less than in the small intestine. However, urea transfer may be significant as the transit time is longer. The quantities of lactulose that can be administered are probably limited by the osmotic activity of this disaccharide, and other carbohydrates of higher molecular weight, such as potato starch or pectin, would be more interesting. The ammonia concentration in the rat caecum (even in the form of $\mathrm{NH}_{3}$ ) has very little effect on the reabsorption of urea nitrogen in the form of ammonia. This reabsorption depends mainly on vein-artery differences in the urea (thus, on caecal irrigation and size) and on blood urea concentration, as we have shown with a high-protein dief or urea overload. The urea appears to diffuse through the caecal wall and is then hydrolyzed by bacterial ureases into ammonia and carbon dioxyde. Thus, the gradient, and possibly the $\mathrm{pH}$, are much more suitable for ammonia absorption near the epithelium than throughout the caecum. In any case, a very acid $\mathrm{pH}$ is not favorable for this ammonia diffusion.

The ratio ammonia $\mathrm{N} /$ urea $\mathrm{N}$ of caecal vein-artery differences was 1 for highly digestible diets, while it was lower with diets including lactose or other complex carbohydrates (crude cereal, seed-cakes). Thus, lower apparent digestibility of dietary nitrogen with undigested carbohydrates (Masson and Palmer, 1973) could correspond to an increased recovery of urea $N$ (originating in the blood) for bacterial protein synthesis.

Commission CNERNA Digestion-Absorption/Association des Physiologistes, Paris 5-6 octobre 1978.

Résumé. Le passage d'urée sanguine dans les contenus digestifs et la réabsorption d'ammoniac ont été étudiés in vivo chez des rats anesthésiés. Les différences artérioveineuses en urée sont plus élevées au niveau du caecum que de l'iléon, de même que l'absorption d'ammoniac. Les surcharges en urée montrent que l'urémie artérielle est un facteur important de la production d'ammoniac. Les substrats glucidiques dans le caecum (glucides membranaires ou lactose) favorisent le développement caecal et la production accrue d'acides gras volatils. On observe dans ces conditions une captation accrue d'urée sanguine ; par contre, l'acidification du contenu caecal ne diminue pas l'absorption de l'ammoniac, bien qu'il y ait une chute considérable de la forme $\mathrm{NH}_{3}$, considérée comme la plus diffusible. Le passage d'urée et l'absorption d'ammoniac sont maximales lorsque les régimes hyperprotéiques sont accompagnés de fermentations caecales importantes. A côté du rôle essentiel de l'urémie sanguine et du développement caecal (irrigation, surface d'échange, activité uréolytique), le pH caecal semble jover un rôle moins évident. Ce fait pourrait correspondre à une hydrolyse de l'urée localisée à proximité de la paroi caecale, dans des conditions de $\mathrm{pH}$ et de substrats distinctes de l'ensemble du caecum.

\section{References}

ARGENZIO R. A., MILLER N., VON ENGELHARD W., 1975. Effect of volatile fatty acids on water and ion absorption in the goat colon. Am. J. Physiol., 229, 997-1002.

BERGMAN E. N., REID R. S., MURRAY M. G., BROCKWAY J. M., WHITELAW F. G., 1965. Interconversions and production of volatile fatty acids in the sheep rumen. Biochem J., 97, 653-660.

BIRCHER J., MULLER P., GUGGENHEIM H., HAEMMERLI U. P., 1966. Treatment of chronic portalsystemic encephalopathy with lactulose. Lancet, 1, 890-893.

CONN H. O., LEEVY C. M., VLAHCEVIC Z. R., RODGERS J. B., MADDREY W. C., SEEFE L., LEVY L. L., 1977. Comparison of lactulose and neomycin in the treatment of chronic portalsystemic encephalopathy. Gastroenterology, 72, 573-583. 
DAVIS C. L., 1967. Acetate production in the rumen of cows fed either control or low-fiber, highgrain diets. J. Dairy Sci., 50, 1621-1629.

DUCLUZEAU R., RAIBAUD P., DICKINSON A. B., SACQUET E., MOQUOT G., 1966. Hydrolyse de l'urée in vitro et in vivo, dans le caecum de rats gnotobioliques par différentes souches bactériennes isolées du tube digestif de rats conventionnels. C. R. Acad. Sci., Paris, 262, 944-946.

GUTMANN I., BERGMEYER H. U., 1974. Determination of urea with glutamate dehydrogenase as indicator enzyme 1794-1798. In BERGMEYER H. U. Methods of enzymatic analysis. Acad. Press, London.

HENNING S. J., HIRD F J. R., 1972. Diurnal variations in the concentrations of volatile fatty acids in the alimentary tract of wild rabbits. Br. J. Nutr., 27, 57-64.

HOOVER W. H., HEITMANN R. N., 1975. Cecal nitrogen metabolism and amino acif absorption in the rabbit. J. Nutr., 105, 245-252.

KIM K., BENEVENGA N. J., GRUMMER R. H., 1978. Estimation of the fraction of the lactose in a high lactose diet available for fermentation in the cecum and colon of the rat. J. Nutr., 108, 79-89.

KNUTSON R. S., FRANCIS J. L., HALL B. H., HEISINGER J. F., 1977. Ammonia and urea distribution and urease activity in the gastrointestinal tract of rabbit (Oryctolagus and Sylvatigus). Comp. Biochem. Physiol., 58, 151-154.

KUN E., KEARNEY E. B., 1974. Ammonia, 1802-1806. In BERGMEYER H. U., Methods of enzymatic analysis. Acad. Press, London.

LEE A., GEMMEL E., 1972. Changes in the mouse intestinal microflora during weaning role of volatile fatty acids. Infect. Immun., 5, 1-7.

MARTY J., RAYNAUD P., CARLES J., 1973. Les acides aminés et les acides carboxyliques dans le caecum du lapin. Ann. Biol. anim. Bioch. Biophys., 13, 429-451.

MASSON V. C., PALMER R., 1973. The influence of bacterial activity in the alimentary canal of rats on caecal nitrogen excretion. Acta agric. scand., 23, 141-149.

MOREAU M. C., DUCLUZEAU R., RAIBAUD P., 1976. Hydrolysis of urea in the gastrointestinal tract of monoxenic rats : effects of immunization with strains of ureolytic bacteria. Infect. Immun., 13, 9-15.

RAIBAUD P., DUCLUZEAU R., MULLER M. C., ABRAMS C., 1972. Diet and the equilibrium between bacteria and yeast implanted in gnotobiotic rats. Am. J. clin. Nutr. 25, 1467-1474.

RÉMÉSY C., DEMIGNÉ C., 1976. Participation and absorption of volatile fatty acids in the alimentary canal of the rat. Ann. Rech. vétér., 7, 39-55.

RÉMÉSY C., DEMIGNÉ C., AUFRÈRE J., 1977. Etude in vivo chez le rat de la production et de l'utilisation de l'acide lactique. Rôle du tube digestif. Ann. Biol. anim. Bioch. Biophys., 17, 607-613.

RÉMÉSY C., DEMIGNÉ C., AUFRÈRE J., 1978. Inter-organ relationships between glucose, lactate and amino acids in rats fed on high-carbohydrate of high-protein diets. Biochem. J., 170, 321-329.

SLADE L. M., BISHOP R., MORRIS J. G., ROBINSON D. G., 1969. Digestion and absorption of ${ }^{15} \mathrm{~N}$-labelled microbial protein in the large intestine of the horse. Brit. Vet., 127, 12-13.

VINCE A., DAWSON A. M., PARK N., O'GRADY F., 1973. Ammonia production by intestinal bacteria. Gut. 14, 171-177.

VINCE A., KILLINGLEY M., WRONG O. M., 1978. Effect of lactulose on ammonia production in a fecal incubation system. Gastroenterology, 74, 544-549.

WOLPERT E., PHILLIPS S. F., SUMMERSKILL W. H., 1971. Transport of urea and ammonia production in the human colon. Lancet, 25, 1387-1390. 